\title{
Selecting Various Industrial Competitors Affect the Risk Level of Viet Nam Hardware Industry During and After the Global Crisis 2007-2011
}

\author{
Dinh Tran Ngoc Huy (Corresponding author) \\ MBA, GSIM, International University of Japan, Japan \\ PhD candidate, Banking University HCMC, Viet Nam
}

Tel: 84-08-093-481-8622Ｅ-mail: dtnhuy2010@gmail.com

Received: December 10, 2013 Accepted: December 23, 2013 Published: December 26, 2013

doi:10.5296/rbm.v1i1.4270 URL: http://dx.doi.org/10.5296/rbm.v1i1.4270

\begin{abstract}
Using a one factor model, this paperwork estimates the impacts of the size of firms' competitors in the hardware industry on the market risk level, measured by equity and asset beta, of 22 listed companies in this category.

This study identified that the risk dispersion level in this sample study could be minimized in case the competitor size doubles (measured by equity beta var of 0,678 ).

Beside, the empirical research findings show us that asset beta min value decreases from 0,054 to 0,030 when the size of competitor doubles.

Last but not least, most of beta values are acceptable. Ultimately, this paper illustrates calculated results that might give proper recommendations to relevant governments and institutions in re-evaluating their policies during and after the financial crisis 2007-2011.
\end{abstract}

Keywords: risk management, competitive firm size, market risk, asset and equity beta, hardware industry

\section{Introduction}

Studies reveal that competition has affected business risk and return. Eugene, French, and Kenneth (2004) also indicated in the three factor model that "value" and "size" are significant components which can affect stock returns. They also mentioned that a stock's return not only depends on a market beta, but also on market capitalization beta. The market beta is used in the three factor model, developed by Fama and French, which is the successor to the CAPM model by Sharpe, Treynor and Lintner. Pagano and Mao (2007) stated that An intermediated 
market can therefore remain viable in the face of competition from a possibly faster, non-intermediated market as long as the specialist can generate revenue for the above services that covers his/her costs associated with asymmetric information, order processing, and inventory management. As Luis E. Peirero (2010) pointed, the task of estimating cost of equity in emerging markets is more difficult because of problems such as collecting data in short periods.

Together with financial system development and the economic growth, throughout many recent years, Viet Nam hardware industry is considered as one of active economic sectors, which has some positive effects for the economy. Additionally, financial risk and reactions has become an issue after the global crisis 2007-2009 which has some certain impacts on the whole Viet nam economy, and specifically, the Viet Nam hardware industry. Hence, this research paper analyzes market risk under a one factor model of these listed firms during this period. The purpose of this study is to find out how much market risk for this industry in changing contexts of competitors.

Therefore, this paperwork will explain not only the relationship between risk and competitor size, but also presents how much risk for the hardware industry in each competitor scenario. It finds out competition or competitor size definitely has certan effects on market risk of listed hardware firms.

This paper is organized as follow. The research issues and literature review will be covered in next sessions 2 and 3, for a short summary. Then, methodology and conceptual theories are introduced in session 4 and 5. Session 6 describes the data in empirical analysis. Session 7 presents empirical results and findings. Next, session 8 covers the analytical results. Then, session 9 will conclude with some policy suggestions. This paper also supports readers with references, exhibits and relevant web sources.

\section{Research Issues}

For the estimating of impacts of a one factor model: the size of competitor on beta for listed hardware industry companies in Viet Nam stock exchange, research issues will be mentioned as following:

Issue 1: Whether the risk level of hardware industry firms under the different changing scenarios of the size of competitor increase or decrease so much.

Issue 2: Whether the disperse distribution of beta values become large in the different changing scenarios of the size of competitor in the hardware industry.

Issue 3: What is the relationship between competitor size and risk minimization?

\section{Literature review}

Black (1976) proposes the leverage effect to explain the negative correlation between equity returns and return volatilities. Diamond and Dybvig (1983) said banks can also help reduce liquidity risk and therefore enable long-term investment. Next, Kim et al. (2002) noted that the nature of competitive interaction in an industry is important in assessing the effect of 
corporate product strategies on shareholder value. Jimenez et al. (2005) pointed As market power is the primary source of franchise value, reduced competition in banking markets has been seen as promoting banking stability.

Umar (2011) found that firms which maintain good governance structures have leverage ratios that are higher (forty-seven percent) than those of firms with poor governance mechanisms per unit of profit. Daly and Hanh Phan (2013) investigated the competitive structure of the banking industries in five emerging asian countries including Viet Nam and showed that the global financial crisis affected dramatically the competition of banking system in emerging Asian countries.

Chen et al. (2013) supported regulators' suspicions that over-reliance on short-term funding and insufficient collateral compounded the effects of dangerously high leverage and resulted in undercapitalization and excessive risk exposure for Lehman Brothers. The model reinforces the importance of the relationship between capital structure and risk management. Then, Alcock et al. (2013) found evidence that leverage cannot be viewed as a long-term strategy to enhance performance, but in the short term, managers do seem to add significantly to fund excess returns by effectively timing leverage choices to the expected future market environment. And Gunaratha (2013) revealed that in different industries in Sri Lanka, the degree of financial leverage has a significant positive correlation with financial risk.

\section{Conceptual theories}

\section{The impact of competition or the size of competitor on the economy and business}

In a competitive hardware market, there are many firms offering the similar products and services and this helps customers select a variety of qualified goods that meet their demand. Competitors could affect price and customer service policies; hence, affect revenues and profits of a typical company. Sources of competition include, but not limit to, training. Increasing training can help competition raising productivity.

Different kinds of market contain various types of risks. And different organizational structure can offer various competition degree.

\section{Methodology}

In this study, analytical research method is used, philosophical method is used and especially, scenario analysis method is used. Analytical data is from the situation of listed hardware material industry firms in $\mathrm{VN}$ stock exchange and applied current tax rate is $25 \%$.

Risk here is assumed understood as fluctuations and volatility of beta which is sometimes higher than 1 or more or lower than that. We use historical and real data on the HNX and HOSE stock exchange in the period 2007-2011 for estimating risk. This is a part of our quantitative analysis method used combined with financial analytical method.

Scenario analysis method is applied in three (3) cases of changing size of competitors under changing competitive strategy. We estimate how much risk in case the firm selects competitor with doubling size, smaller size and approximate size. And beta results can be used for 


\section{Macrothink

CAPM model to estimate WACC or cost of capital if readers want to go to further steps. In later sessions, we will explain the relationship between competitor size and beta. When we mention the competitor selecting strategy, we stand from the point of view of firm management, although the calculated results can be used for various stakeholders including investors.

In the below table 1, 2, 3 and others, the symbols such as "VTC" will represent for stock code of each listed firm on the stock exchange.

Finally, we use the results to suggest policy for both these enterprises, relevant organizations and government.

\section{General Data Analysis}

The research sample has total 22 listed firms in the hardware industry market with the live data from the stock exchange.

Firstly, we estimate equity and asset beta values of these firms, as well as the risk dispersion. Secondly, we change the competitor size from aprroxiamte size to doubling size and slightly smaller size to see the sensitivity of beta values. We figure out that in 3 cases, asset beta mean values are estimated at 0,441,0,393 and 0,430 which are negatively correlated with the size of competitors. Also in 3 scenarios, we find out equity beta mean values $(0,748,0,678$ and $0,728)$ are also negatively correlated with the competitive firm size. Various competitors selected definitely have certain effects on asset and equity beta values.

\section{Empirical Research Findings and Discussion}

In the below section, data used are from total 22 listed hardware industry companies on VN stock exchange (HOSE and HNX mainly). In the scenario 1, current financial leverage degree is kept as in the 2011 financial statements which is used to calculate market risk (beta) whereas competitor size is kept as current, then changed from double size to slightly smaller size. Then, two (2) FL scenarios are changed up to $30 \%$ and down to $20 \%$, compared to the current FL degree. In short, the below table 1 shows three scenarios used for analyzing the risk level of these listed firms.

Market risk (beta) under the impact of tax rate, includes: 1) equity beta; and 2) asset beta.

Table 1. Analyzing market risk under three (3) scenarios (Made by Author)

\begin{tabular}{|c|c|}
\hline & FL as current \\
\hline Competitor size as current & Scenario 1 \\
\hline Competitor size slightly smaller & Scenario 2 \\
\hline Competitor size double & Scenario 3 \\
\hline
\end{tabular}

\subsection{Scenario 1: current financial leverage and competitor size kept as current}

In this case, all beta values of 22 listed firms on VN hardware industry market as following: 
Table 2. Market risk of listed companies on VN hardware industry market under one factor model (case 1) (source: VN stock exchange 2012)

\begin{tabular}{|c|c|c|c|c|c|}
\hline $\begin{array}{l}\text { Order } \\
\text { No. }\end{array}$ & $\begin{array}{l}\text { Company } \\
\text { stock code }\end{array}$ & $\begin{array}{l}\text { Equity } \\
\text { beta }\end{array}$ & $\begin{array}{c}\text { Asset beta } \\
\text { (assume debt beta } \\
=0 \text { ) }\end{array}$ & Note & $\begin{array}{c}\text { Financial } \\
\text { leverage }(\mathrm{F} . \mathrm{S} \\
\text { reports })\end{array}$ \\
\hline 1 & $\mathrm{CMT}$ & 0,665 & 0,326 & & $51,1 \%$ \\
\hline 2 & SVT & 0,860 & 0,651 & $\begin{array}{c}\text { TLC as } \\
\text { comparable }\end{array}$ & $24,2 \%$ \\
\hline 3 & VIE & 0,283 & 0,054 & $\begin{array}{c}\text { UNI as } \\
\text { comparable }\end{array}$ & $81,0 \%$ \\
\hline 4 & HPT & 0,238 & 0,063 & $\begin{array}{c}\text { TST as } \\
\text { comparable }\end{array}$ & $73,7 \%$ \\
\hline 5 & NIS & 0,347 & 0,165 & $\begin{array}{c}\text { VTC as } \\
\text { comparable }\end{array}$ & $52,5 \%$ \\
\hline 6 & TST & 0,739 & 0,236 & & $68,1 \%$ \\
\hline 7 & ST8 & 0,891 & 0,682 & & $23,5 \%$ \\
\hline 8 & TAG & 0,632 & 0,411 & & $35,0 \%$ \\
\hline 9 & POT & 1,046 & 0,533 & & $49,0 \%$ \\
\hline 10 & $\mathrm{CKV}$ & 0,604 & 0,221 & & $63,5 \%$ \\
\hline 11 & ONE & 0,551 & 0,217 & $\begin{array}{c}\text { UNI as } \\
\text { comparable }\end{array}$ & $60,6 \%$ \\
\hline 12 & PMT & 1,234 & 1,056 & & $14,4 \%$ \\
\hline 13 & SMT & 0,934 & 0,654 & $\begin{array}{c}\text { PMT as } \\
\text { comparable }\end{array}$ & $30,0 \%$ \\
\hline 14 & UNI & 1,186 & 0,732 & & $38,3 \%$ \\
\hline 15 & TLC & 1,066 & 0,770 & & $27,8 \%$ \\
\hline 16 & KST & 0,679 & 0,386 & $\begin{array}{c}\text { TLC as } \\
\text { comparable }\end{array}$ & $43,1 \%$ \\
\hline 17 & VAT & 1,028 & 0,485 & & $52,8 \%$ \\
\hline 18 & VTC & 0,635 & 0,431 & & $32,2 \%$ \\
\hline 19 & ELC & 0,200 & 0,100 & $\begin{array}{c}\text { ITD as } \\
\text { comparable }\end{array}$ & $50,0 \%$ \\
\hline 20 & SAM & 1,191 & 1,069 & & $10,2 \%$ \\
\hline 21 & LTC & 1,102 & 0,329 & & $70,2 \%$ \\
\hline 22 & ITD & 0,351 & 0,132 & & $62,5 \%$ \\
\hline & & & & Average & $46,1 \%$ \\
\hline
\end{tabular}




\subsection{Scenario 2: Competitor Size Double}

All beta values of total 22 listed firms on VN hardware industry market as below:

Table 3. Market risks of listed hardware industry firms under one factor model (case 2) (source: VN stock exchange 2012)

\begin{tabular}{|c|c|c|c|c|}
\hline $\begin{array}{l}\text { Order } \\
\text { No. }\end{array}$ & $\begin{array}{l}\text { Company stock } \\
\text { code }\end{array}$ & $\begin{array}{l}\text { Equity } \\
\text { beta }\end{array}$ & $\begin{array}{l}\text { Asset beta (assume } \\
\text { debt beta }=0)\end{array}$ & Note \\
\hline 1 & $\mathrm{CMT}$ & 0,665 & 0,326 & \\
\hline 2 & SVT & 0,212 & 0,161 & VIE as comparable \\
\hline 3 & VIE & 0,263 & 0,050 & LTC as comparable \\
\hline 4 & HPT & 0,113 & 0,030 & ITD as comparable \\
\hline 5 & NIS & 0,487 & 0,231 & ST8 as comparable \\
\hline 6 & TST & 0,739 & 0,236 & \\
\hline 7 & ST8 & 0,891 & 0,682 & \\
\hline 8 & TAG & 0,632 & 0,411 & \\
\hline 9 & POT & 1,046 & 0,533 & \\
\hline 10 & $\mathrm{CKV}$ & 0,604 & 0,221 & \\
\hline 11 & ONE & 0,294 & 0,116 & TAG as comparable \\
\hline 12 & PMT & 1,191 & 1,019 & \\
\hline 13 & SMT & 0,369 & 0,258 & NIS as comparable \\
\hline 14 & UNI & 1,186 & 0,732 & \\
\hline 15 & TLC & 1,066 & 0,770 & \\
\hline 16 & KST & 0,168 & 0,095 & VIE as comparable \\
\hline 17 & VAT & 1,168 & 0,551 & \\
\hline 18 & VTC & 0,635 & 0,431 & \\
\hline 19 & ELC & 0,542 & 0,271 & CMG as comparable \\
\hline 20 & SAM & 1,191 & 1,069 & \\
\hline 21 & LTC & 1,102 & 0,329 & \\
\hline 22 & ITD & 0,351 & 0,132 & \\
\hline
\end{tabular}

\subsection{Scenario 3: Competitor Size Slightly Smaller}

All beta values of total 22 listed firms on the hardware industry market in $\mathrm{VN}$ as following: 
Table 4. Market risk of listed hardware industry firms under one factor model (case 3) (source: VN stock exchange 2012)

\begin{tabular}{|c|c|c|c|c|}
\hline $\begin{array}{l}\text { Order } \\
\text { No. }\end{array}$ & $\begin{array}{l}\text { Company stock } \\
\text { code }\end{array}$ & $\begin{array}{l}\text { Equity } \\
\text { beta }\end{array}$ & $\begin{array}{c}\text { Asset beta (assume } \\
\text { debt beta }=0)\end{array}$ & Note \\
\hline 1 & $\mathrm{CMT}$ & 0,665 & 0,326 & \\
\hline 2 & SVT & 0,860 & 0,651 & TLC as comparable \\
\hline 3 & VIE & 0,131 & 0,025 & ONE as comparable \\
\hline 4 & HPT & 0,238 & 0,063 & TST as comparable \\
\hline 5 & NIS & 0,347 & 0,165 & VTC as comparable \\
\hline 6 & TST & 0,739 & 0,236 & \\
\hline 7 & ST8 & 0,891 & 0,682 & \\
\hline 8 & TAG & 0,632 & 0,411 & \\
\hline 9 & POT & 1,046 & 0,533 & \\
\hline 10 & $\mathrm{CKV}$ & 0,604 & 0,221 & \\
\hline 11 & ONE & 0,551 & 0,217 & UNI as comparable \\
\hline 12 & PMT & 1,191 & 1,019 & \\
\hline 13 & SMT & 0,826 & 0,578 & HTP as comparable \\
\hline 14 & UNI & 1,186 & 0,732 & \\
\hline 15 & TLC & 1,066 & 0,770 & \\
\hline 16 & KST & 0,405 & 0,230 & VTC as comparable \\
\hline 17 & VAT & 1,168 & 0,551 & \\
\hline 18 & VTC & 0,635 & 0,431 & \\
\hline 19 & ELC & 0,200 & 0,100 & ITD as comparable \\
\hline 20 & SAM & 1,191 & 1,069 & \\
\hline 21 & LTC & 1,102 & 0,329 & DTL as comparable \\
\hline 22 & ITD & 0,351 & 0,132 & BVG as comparable \\
\hline
\end{tabular}

All three above tables and data show that values of equity and asset beta in the three cases of changing competiotor size have certain fluctuation.

\section{Comparing statistical results in 3 scenarios of changing leverage:}

Table 5. Statistical results (FL in case 1) (source: VN stock exchange 2012)

\begin{tabular}{|c|c|c|c|}
\hline Statistic results & Equity beta & Asset beta (assume debt beta = 0) & Difference \\
\hline MAX & 1,234 & 1,069 & 0,165 \\
\hline MIN & 0,200 & 0,054 & 0,147 \\
\hline MEAN & 0,748 & 0,441 & 0,307 \\
\hline
\end{tabular}




\begin{tabular}{|l|r|r|r|} 
VAR & 0,1085 & 0,0893 & 0,019 \\
\hline \multicolumn{3}{|c|}{ Note: Samle size 22 firms } \\
\hline
\end{tabular}

Table 6. Statistical results (FL in case 2) (source: VN stock exchange 2012)

\begin{tabular}{|c|c|c|c|}
\hline Statistic results & Equity beta & Asset beta (assume debt beta = 0) & Difference \\
\hline MAX & 1,191 & 1,069 & 0,1217 \\
\hline MIN & 0,113 & 0,030 & 0,0833 \\
\hline MEAN & 0,678 & 0,393 & 0,2846 \\
\hline VAR & 0,1392 & 0,0903 & 0,0489 \\
\hline \multicolumn{4}{|c|}{ Note: Sample size : 22} \\
\hline
\end{tabular}

Table 7. Statistical results (FL in case 3) (source: VN stock exchange 2012)

\begin{tabular}{|c|c|c|c|}
\hline Statistic results & Equity beta & Asset beta (assume debt beta = 0) & Difference \\
\hline MAX & 1,191 & 1,069 & 0,1217 \\
\hline MIN & 0,131 & 0,025 & 0,1064 \\
\hline MEAN & 0,728 & 0,430 & 0,2980 \\
\hline VAR & 0,1226 & 0,0894 & 0,0332 \\
\hline \multicolumn{4}{|c|}{ Note: Sample size : 22} \\
\hline
\end{tabular}

Based on the calculated results, we find out:

First of all, Equity beta mean values in all 3 scenarios are acceptable $(<0,8)$ and asset beta mean values are also small $(<0,5)$. In the case of reported leverage in 2011 , equity beta max is 1,234 which is somewhat acceptable. If competitor size doubles, equity beta min decreases from 0,200 to 0,113 . Finally, when competitor size is slightly smaller, asset beta min decreases from 0,054 to 0,025 .

The below chart 1 shows us : when competitive firm size decreases slightly, average equity beta value decrease slightly $(0,728)$ compared to that at the initial selected competitor $(0,748)$. Next, average asset beta decreases little (to 0,430$)$. However, in case the competitor size doubles, the risk level of the selected firms decreases little more $(0,393)$. Last but not least, the fluctuation of equity beta value $(0,139)$ in the case of doubling size competitors is higher than $(>)$ the results in the rest 2 cases. And we could note that in the case competitor size slightly smaller, the risk is less dispersed $(0,089)$. 


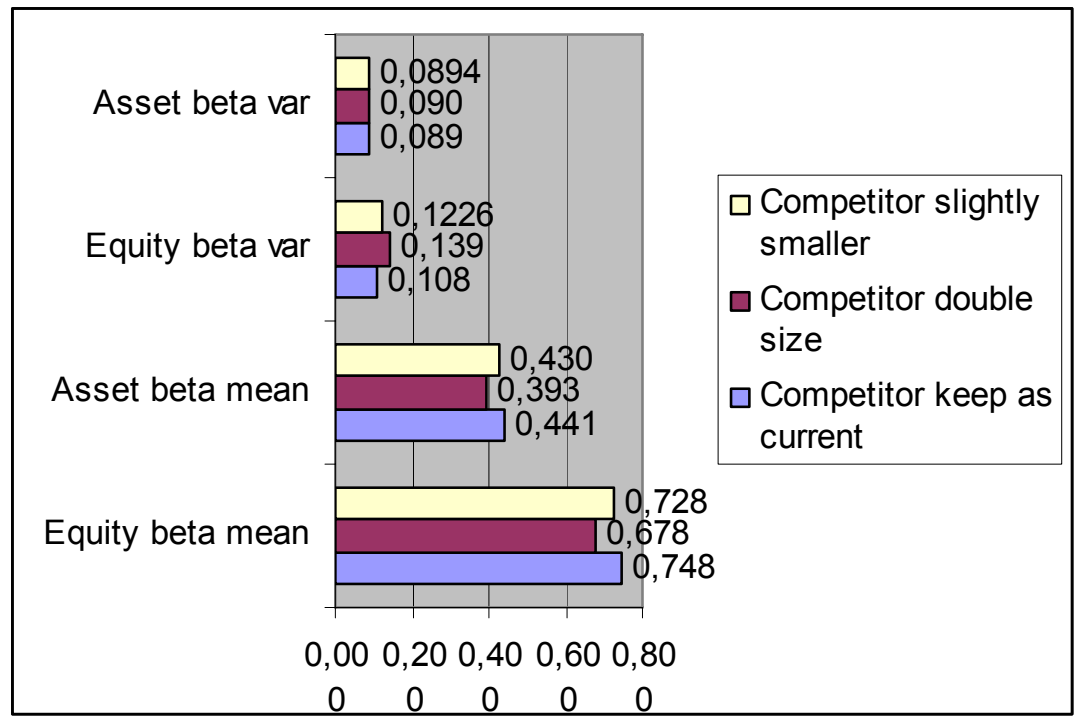

Chart 1. Comparing statistical results of equity beta var and mean in three (3) scenarios of changing competitor size (source: VN stock exchange 2012)

\section{Conclusion and Policy suggestion}

In conclusion, the government has to consider the impacts on the mobility of capital in the markets when it changes the macro policies and the legal system and regulation for developing the hardware market. The Ministry of Finance continues to increase the effectiveness of fiscal policies and tax policies which are needed to combine with other macro policies at the same time. The State Bank of Viet Nam continues to increase the effectiveness of capital providing channels for hardware companies as we could note that in this study when competitive firm size doubles, the risk level decreases (equity beta mean value is estimated at: 0,678$)$, and the equity beta var value $(0,139)$ is little higher than that in case competitor size as current $(0,108)$.

Furthermore, the entire efforts among many different government bodies need to be coordinated.

Finally, this paper suggests implications for further research and policy suggestion for the Viet Nam government and relevant organizations, economists and investors from current market conditions.

\section{Acknowledgements}

I would like to take this opportunity to express my warm thanks to Board of Editors and Colleagues at Citibank-HCMC, SCB and BIDV-HCMC, Dr. Chen and Dr. Yu Hai-Chin at Chung Yuan Christian University for class lectures, also Dr Chet Borucki, Dr Jay and my ex-Corporate Governance sensei, Dr. Shingo Takahashi at International University of Japan. My sincere thanks are for the editorial office, for their work during my research. Also, my warm thanks are for Dr. Ngo Huong, Dr. Ho Dieu, Dr. Ly H. Anh, Dr Nguyen V. Phuc and my 


\section{Macrothink}

lecturers at Banking University - HCMC, Viet Nam for their help.

Lastly, thank you very much for my family, colleagues, and brother in assisting convenient conditions for my research paper.

\section{References}

Chen, R. R., Chidambaran, N. K., Imerman, M. B., \& Sopranzetti, B. J. (2013). Liquidity, Leverage, and Lehman: A Structural Analysis of Financial Institutions in Crisis. Fordham School of Business Research Paper No.2279686.

Dexheimer, J., \& Haugen, C. (2003). Sarbanes-Oxley: Its Impact on the Venture Capital Community, Minnesota Journal of Business Law and Entrepreneurship, 2(1).

Fama, E. F., \& French, K. R. (2004). The capital asset pricing model: theory and evidence. The Journal of Economic Perspectives, 18(3), 25-46. http://dx.doi.org/10.1257/0895330042162430

Flifel, K. (2012). Financial Markets between Efficiency and Persistence : Empirical Evidence on Daily Data. Asian Journal of Finance and Accounting, 4(2), 379-400. http://dx.doi.org/10.5296/ajfa.v4i2.1827

Gunaratha, V. (2013). The Degree of Financial Leverage as a Determinant of Financial Risk: An Empirical Study of Colombo Stock Exchange in Sri Lanka. 2nd International Conference on Management and Economics Paper.

Huy, D. T. N. (2013). Estimating Beta of Viet Nam Listed Public Utilities, Natural Gas and Oil Company Groups During and After The Financial Crisis 2007-2011. Economic and Business Review, 15(1), 57-71

Lawrence, S. et al. (2001). Persistence of Web References in Scientific Research. Computer, 34, 26-31. http://dx.doi.org/10.1109/2.901164

Ling, A. (2013), Tax Issues Relating to Intangibles, Asia-Pacific Tax Bulletin.

Litvak, K. (2008). Defensive Management: Does the Sarbanes-Oxley Act Discourage Corporate Risk-Taking?, Law and Economics Research Paper, No. 108.

Mamun, M. A. A. (2013). Performance Evaluation of Prime Bank Limited in Terms of Capital Adequacy. Global Journal of Management and Business Research, 13(9), 26-29.

Ovat, O. O. (2013). Liquidity Constraints and Entrepreneurial Financing in Nigeria: The Fate of Fresh Graduate Entrepreneurs. Global Journal of Management and Business Research, 13(9), 49-57.

Zhang, I. X. (2007). Economic consequences of the Sarbanes-Oxley Act of 2002. Journal of Accounting and Economics, 44(1), 74-115. http://dx.doi.org/10.1016/j.jacceco.2007.02.002 


\section{Appendix}

Appendix 1. Inflation, GDP growth and macroeconomics factors

\begin{tabular}{|c|c|c|c|}
\hline Year & Inflation & GDP & USD/VND rate \\
\hline 2011 & $18 \%$ & $5,89 \%$ & 20.670 \\
\hline 2010 & $11,75 \%$ (Estimated at Dec 2010) & $6,5 \%$ (expected) & 19.495 \\
\hline 2009 & $6,88 \%$ & $5,2 \%$ & 17.000 \\
\hline 2008 & $22 \%$ & $6,23 \%$ & 17.700 \\
\hline 2007 & $12,63 \%$ & $8,44 \%$ & 16.132 \\
\hline 2006 & $6,6 \%$ & $8,17 \%$ & \\
\hline 2005 & $8,4 \%$ & & \\
\hline Note & \multicolumn{2}{|c}{ approximately } \\
\hline
\end{tabular}

(source: Viet Nam commercial banks and economic statistical bureau).

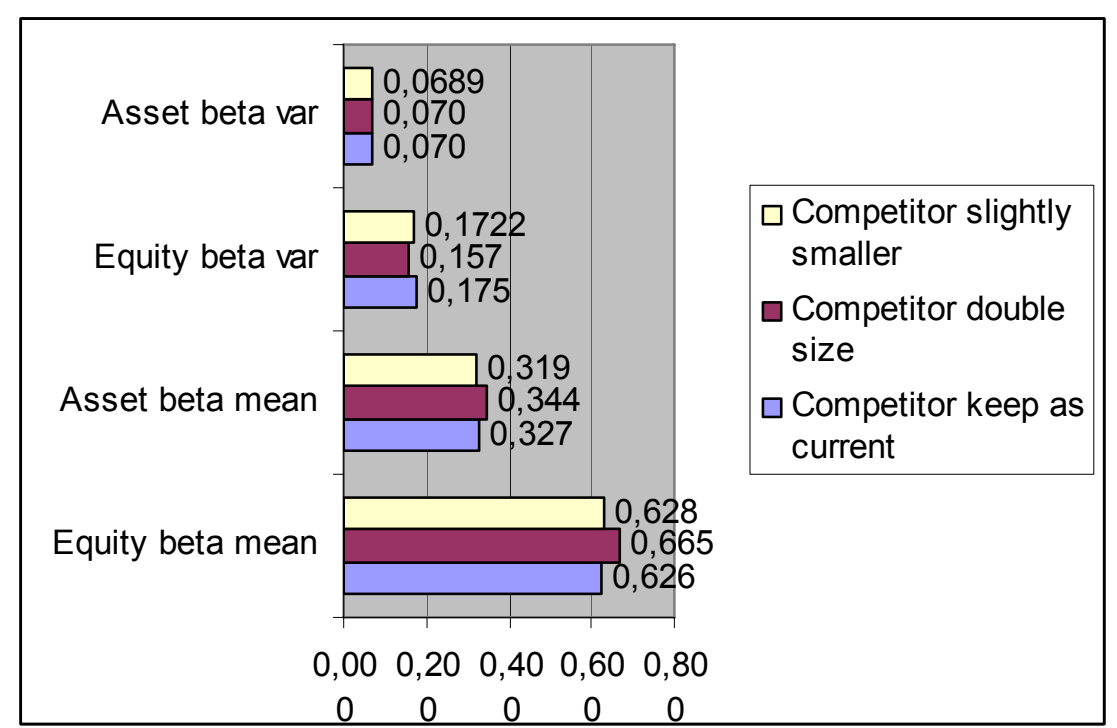

Appendix 2. Comparing statistical results of equity beta var and mean in three (3) scenarios of changing competitor size in the commercial electric industry

Source: VN stock exchange 2012.

\section{Copyright Disclaimer}

Copyright reserved by the author(s).

This article is an open-access article distributed under the terms and conditions of the Creative Commons Attribution license (http://creativecommons.org/licenses/by/3.0/). 